\title{
FLOOD HAZARD IN THE CITY OF CHEMORA (ALGERIA)
}

\author{
Guellouh SAMI * \\ Laboratory LRNAT, University of Batna-2, Algeria, \\ e-mail: guellouhsami@gmail.com \\ Filali ABDELWAHHAB \\ Laboratory LRNAT, University of Batna-2, Algeria, \\ e-mail: abdelwahhabfilali@gmail.com \\ Habibi YAHYAOUI \\ Laboratory LRNAT, University of Batna-2, Algeria, \\ e-mail: y.habibi@univ-batna2.dz \\ Fateh ABDELGHANI \\ Laboratory LRNAT, University of Batna-2, Algeria, \\ e-mail: ghaniifatah9@gmail.com
}

Citation: Sami, G., Abdelwahhab, F., Yahyaoui, H., \& Abdelghani, F. (2021). Flood Hazard in the City of Chemora (Algeria). Analele Universităţii din Oradea, Seria Geografie, 31(1), 22-27. https://doi.org/10.30892/auog.311103-835

\begin{abstract}
Floods become major concerns in most gobe regions due to socio-economic and environmental consequences caused by these phenomena in recent decades. Most Algerian cities are exposed to flood risks and suffered from its consequences. The purpose of this paper is the spatialization of flood hazard in the city of Chemora (Algeria) by hydraulic modelling in a GIS environment whose objective is prevention, which requires a set of hydrological and hydraulic informations in order to achieve a comprehensive and effective management.
\end{abstract}

Key words: Floods, Hydraulic modelling, GIS, Prevention

$* \quad * \quad * \quad * \quad * \quad *$

\section{INTRODUCTION}

Flood risk is one of the most devastating natural hazards that cause loss of lives, damage to properties, resources and environmental degradation in urban areas (Forkou, 2011). In 2011, they were reported to be the third most common disaster, after earthquake and tsunami, with 5202 deaths and adducing millions of people (CRED, 2012; Sami et al., 2016). Floods are the number one natural disaster in the world, causing approximately 20,000 victims per year (Simona and Cedric, 2007). Like the rest of the world, the Mediterranean region has experienced multiple 
floods which are becoming an increasingly formidable threat (Rifai et al., 2014). Algeria has experienced floods that have caused widespread and often irreversible damage.

Often, the food management requires a set of hydrological and hydraulic informations; Firstly, hydrology encompasses all the processes which lead to the determination of flows in a river, associated with their probability of occurrence. There are two approaches in the hydrology: the deterministic approach and the statistical approach.

- The deterministic approach considers all factors that may influence the watershed response and introduces them into a model for flow estimation.

- The statistical approach allows the estimation of flows, of a given probability, from statistical laws that have been adjusted from series of measured flow data (Blin, 2001).

In this context, the flood is a very complex natural phenomenon, whose analysis requires efficient and elaborate tools, for example hydraulic models. The main purpose of hydraulic models is to simulate hypothetical or real floods numerically, which makes it possible to characterize the hazards in space and time (water levels, flow rates, times of submersion, etc.).

Secondly, Hydraulics refers to applications, calculations and treatments which allow water levels to be obtained from flow rates calculated at the scale of watercourse section.

Therefore, hydrology is the discipline which allows getting the flows and their return periods. Hydraulics is the discipline that makes it possible to obtain the water levels and the speeds corresponding to these flows.

In fine, the map of flood risk areas requires a modeling by GIS (Herman, 2009, 2010) and hydraulic simulation software.This modelling aims to quantitatively measure the risk at any appropriate division of the territory.

\section{STUDY AREA}

The city of Chemora is located in Eastern Algeria, at $41 \mathrm{~km}$ east of the county seat of the wilaya of Batna (Figure 1). It covers an area of $261360 \mathrm{~km}^{2}$, between $35^{\circ} 30^{\prime}$ and $35^{\circ} 45^{\prime}$ north and between $6^{\circ}$ $25^{\prime}$ and $6^{\circ} 45^{\prime}$ east, regrouping a population of 13743 inhabitants in 2008 (Sami et al., 2020).

This city is divided into two parts by the passage of a river in their territory. The city of Chemora has undergone several rainy episodes that have generated significant flooding.

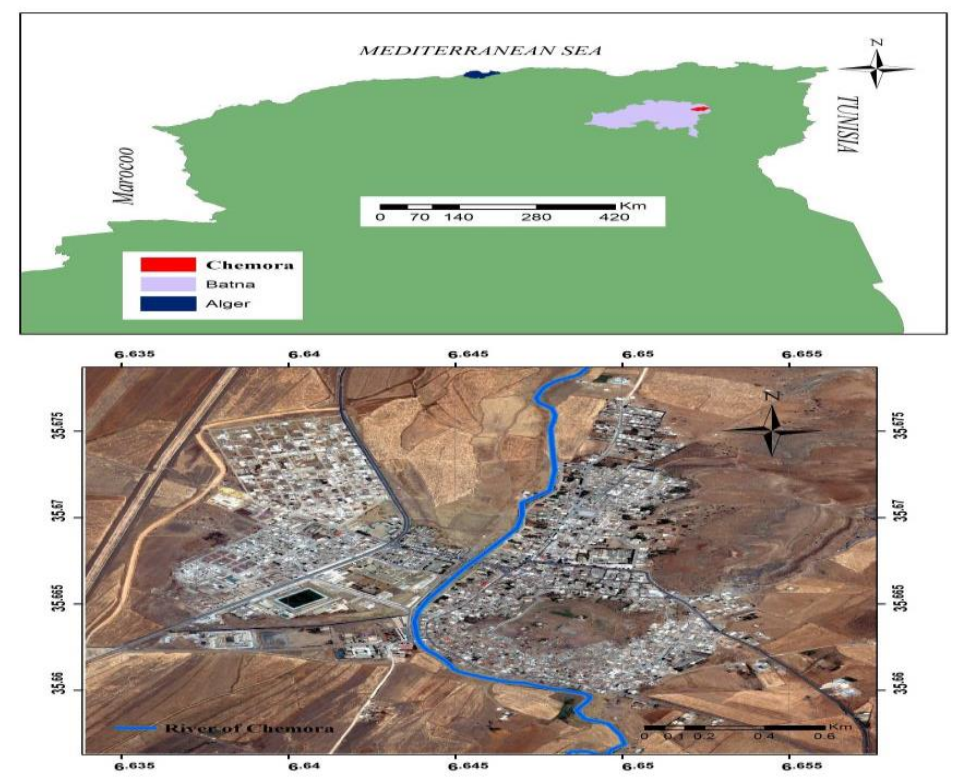

Figure 1. Study area 


\section{MATERIALS AND METHODS}

Two complementary steps were carried (hydrological modelling and hydraulic modelling) to map the flood hazard in the city of Chemora.

\section{Hydrological modeling}

Peak flow estimation requires a frequency analysis of the annual flow series registered in the hydrometric station of Chemora Oued (river). This was achieved by the application of the empirical laws, namely Gumbel's law (the most widely used law in the Mediterranean region). This proceeding allowed estimating the quantiles of the extreme flows for different return periods,

The series of flows recorded at hydrometric station of Oued Chemora covers a period of 37 years 1969 - 2012 (ANRH). The sample is constituted by extracting the maximum daily value for each year.

The methodology of the maximum values for each year appeared to be generally preferred to the methodology of data above a threshold, both by researchers and by developers (Cunnane, 1987).

Table 1. Statistical parameters of hydrometric station data

\begin{tabular}{|c|c|c|c|c|c|}
\hline parameters & $\begin{array}{c}\text { Value min } \\
\left(\mathrm{m}^{3} / \mathrm{s}\right)\end{array}$ & $\begin{array}{c}\text { Value max } \\
\left(\mathrm{m}^{3} / \mathrm{s}\right)\end{array}$ & $\begin{array}{c}\text { Average } \\
\text { value }\left(\mathrm{m}^{3} / \mathrm{s}\right)\end{array}$ & $\begin{array}{c}\text { Coefficient of } \\
\text { asymmetry }(\mathrm{CA})\end{array}$ & $\begin{array}{c}\text { Coefficient } \\
\text { of variation }(\mathrm{CV})\end{array}$ \\
\hline Series of flows & 5 & 231 & 122 & 0.030 & 0.203 \\
\hline
\end{tabular}

Gumbel's law is a particular case of the GEV law or $\mathrm{K}=0$, this statistical distribution is a frequency model is often used to describe the statistical behaviour of extreme values (Wilcoxon, 1945), because it allows a linear adjustment from a double exponential law according to a method described in Gumbel, 1958 and illustrated in Fallot J. M., (2013).

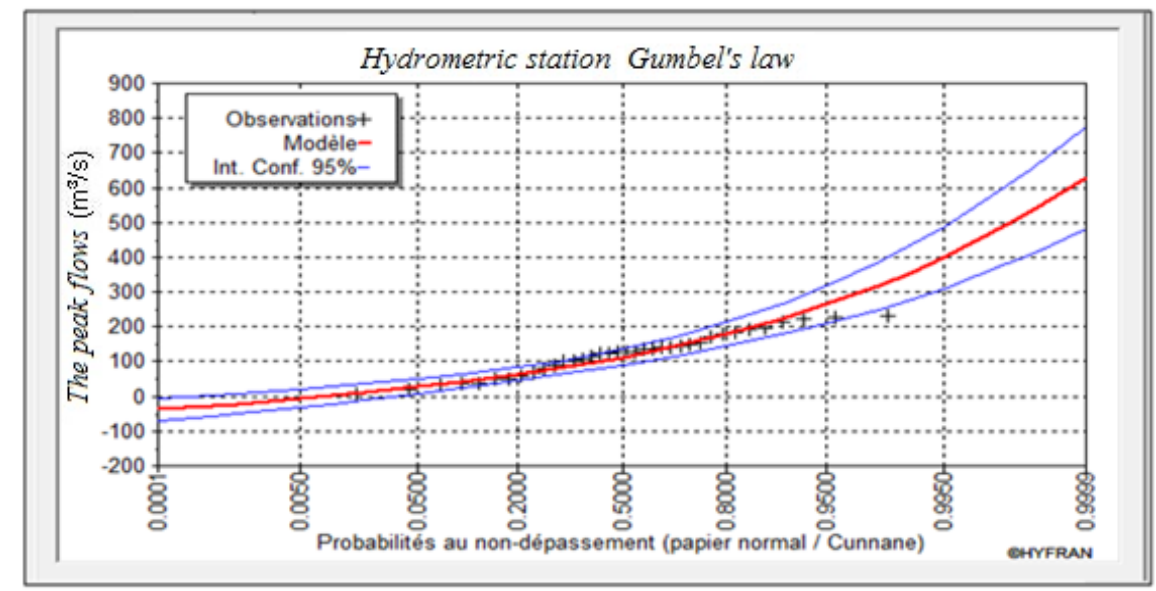

Figure 2. Adjustment of peak flows through Gumbel's law

\section{Hydraulic modeling}

The objective of this approach is to map floods for a 100-year return period and delimit areas that may be affected; this approach requires a fine analysis based on modelling in a GIS under (QGIS) with their extension (Q-RAS) and hydraulic modelling software (HEC-RAS).

Indeed, this approach is exploited to analyze flows and water levels in river beds and to identify flood areas, integrating many data entry, hydraulic analysis components, data storage in the form of tables and graphs.

After the creation of TIN (Triangular Irrigular Network) required format for analysis under QGIS from DEM (Degital Elevation Model) of $30 \mathrm{~m}$ resolution, the modelling of stream geometry is necessary, namely the central flow and cross sections (figure 3 ). 


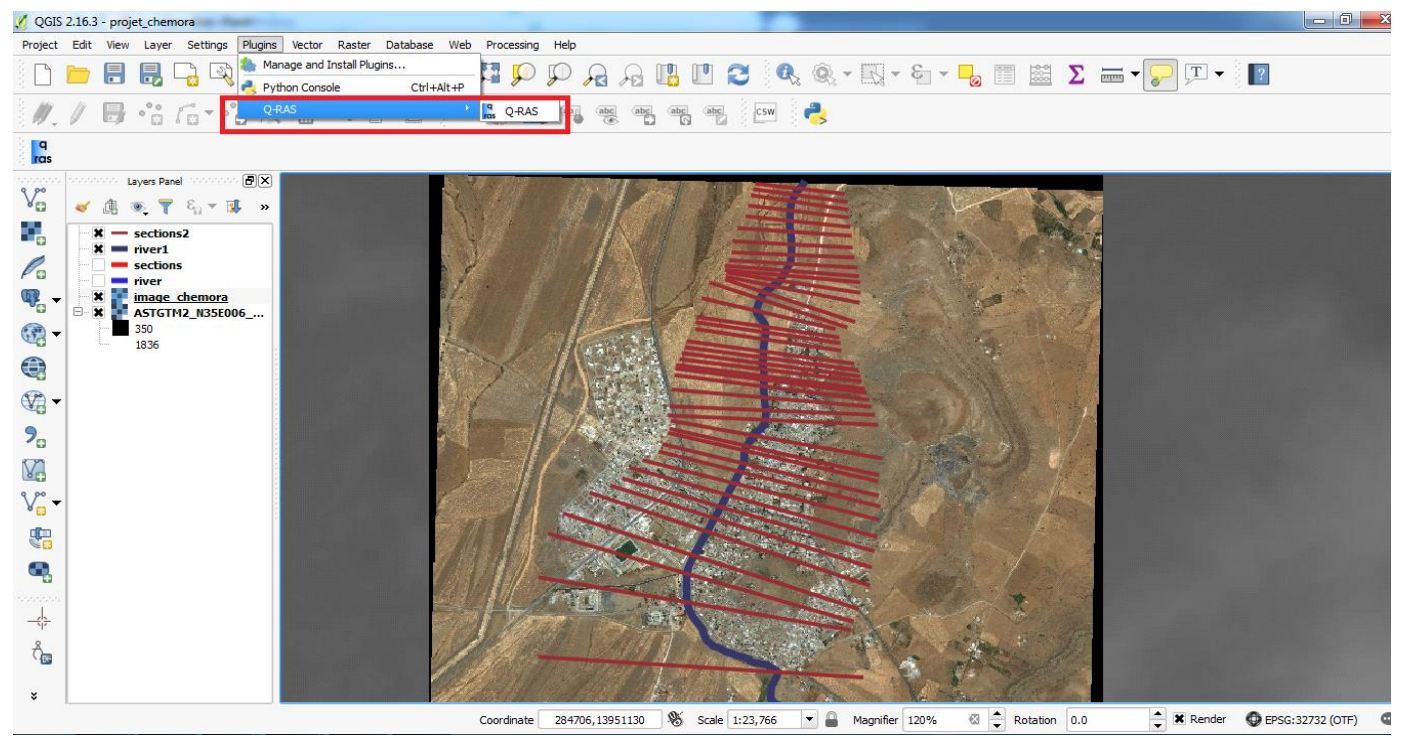

Figure 3. The modelling of stream geometry under QGIS

A land cover map has been integrated as a Manning coefficient that represents the roughness of the beds according to the nature and type of the soil.

The Q-RAS extension allows the extraction of the topography (of the entities realized) and exports it to the HEC-RAS software which ensures hydraulic simulation to integrate the 100 -year flow value and boundary conditions for each section as a normal slope.

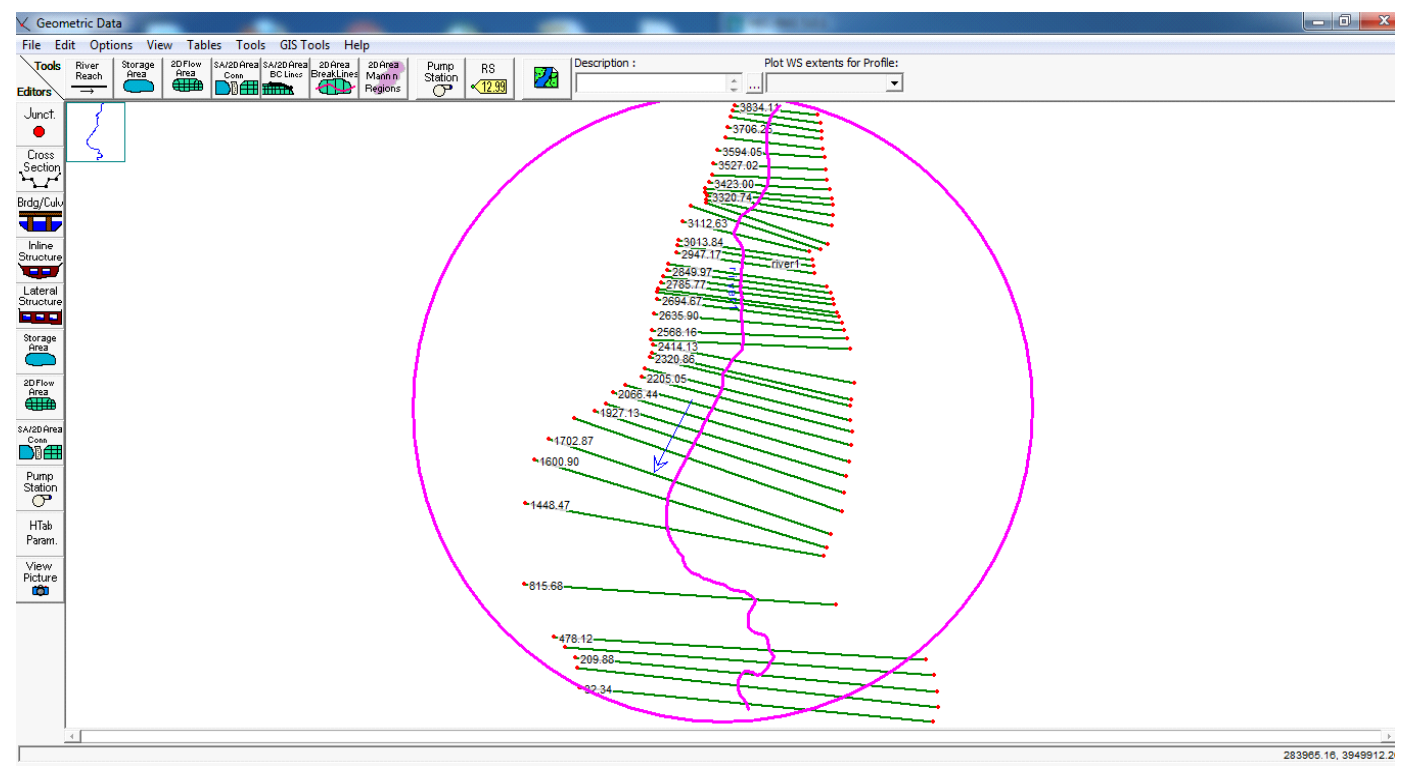

Figure 4. The stream geometry under HEC-RAS

Integration of technologies HEC-RAS (Hydrologic Engineering Centers River Analysis System) and GIS (Geographic Information System) to obtain scientifically derived information has been specified as efficient in simulating, identifying and analyzing flood events in a geo-spatial environment (Shamsi et al., 2002; Sami et al., 2016). 


\section{RESULTS AND DISCUSSIONS}

The results of the hydrological modelling of the flows recorded by the Chemora stream station are summarized in the table below.

Table 2. Peak flow for different return periods

\begin{tabular}{|c|c|c|c|c|}
\hline return periods & 10 ans & 50 ans & $\mathbf{1 0 0}$ ans & 1000 ans \\
\hline Peak flow $\left(\mathbf{m}^{\mathbf{3}} / \mathbf{s}\right)$ & 198 & 232 & $\mathbf{2 4 2}$ & 260 \\
\hline
\end{tabular}

The results of the hydraulic simulation after the integration of 100-year recurrent flows are shown in the figure 5 .

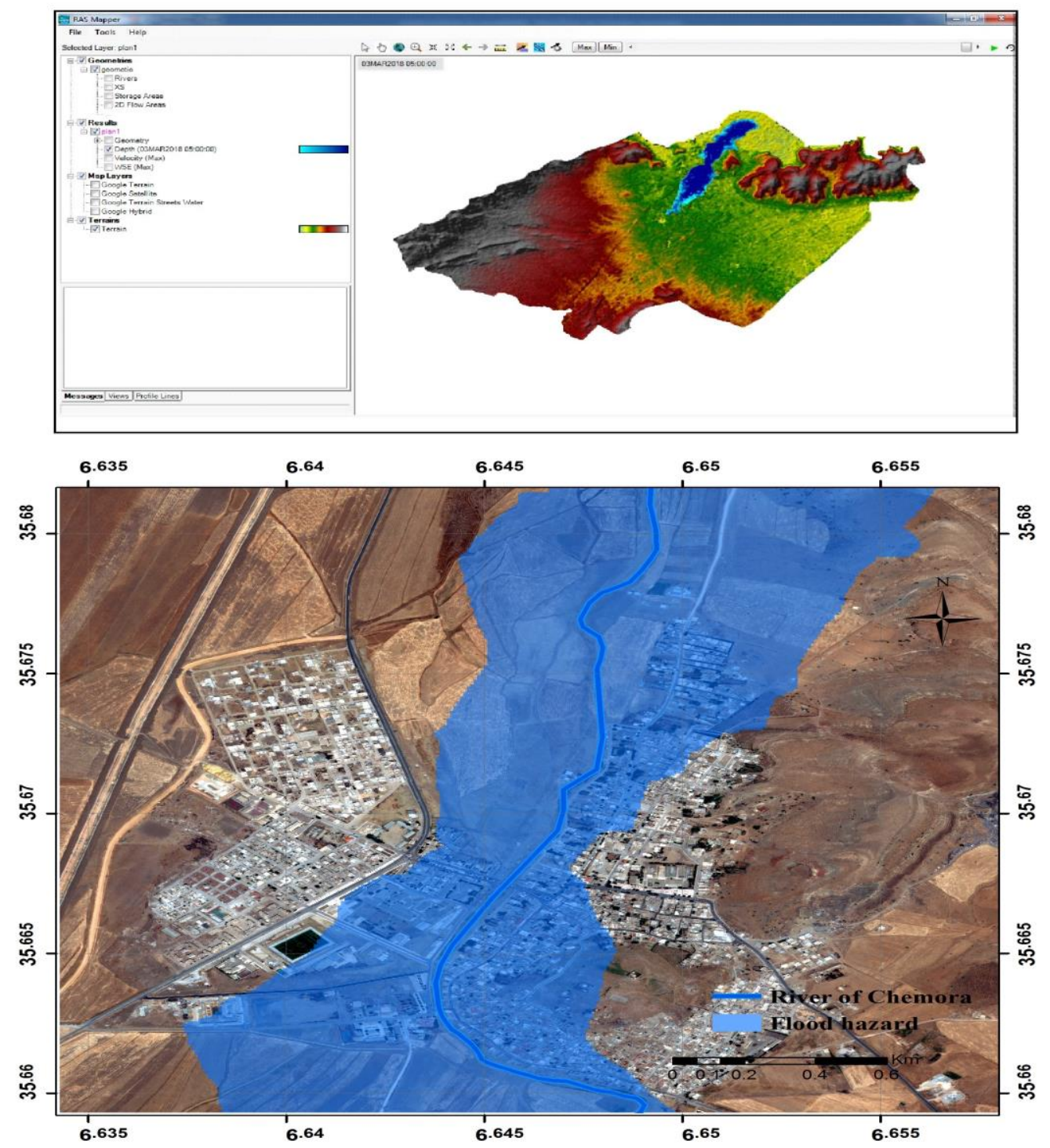

Figure 5. The results of the hydraulic simulation (100-year recurrent flows) 
According to the map a several important socio-economic issues are exposed, in particular the equipment that constitutes the source areas (who are participating in crisis management) can potentially be affected which makes management very difficult in this case.

A precise knowledge of socio economic information will contribute to apprehend this risk with more efficiency.

Data availability has a very important role in the choice and the efficiency of the methodological approach used (Guellouh and al, 2016).

\section{CONCLUSION}

The objective of this study is to map flood hazard in the city of Chemorab, applied GIS and simulation software (which are pertinent tools in spatializing floods and knowledge of submersion elevation), whom helps to establish a strategy to face up to river dynamics and the damage that may result. Hydraulic modelling with this technique has proven an efficiency and effectiveness in the diagnostic of overflow of watercourses risk according to several authors and researchers.

Finally, a more accurate knowledge of territorial socio-economic data will contribute to a more effective management of this risk.

\section{REFERENCES}

Blin, P. (2001). Développement d'une nouvelle méthode de cartographie du risque unitaire d'inondation (crue) pour des résidences (Doctoral dissertation, Université du Québec, Institut national de la recherche scientifique).

Cunnane, C. (1987). Review of statistical models for flood frequency estimation. In Hydrologic frequency modeling (pp. 49-95). Springer, Dordrecht.

CRED (2016). The OFDA/CRED-International Disaster Database Université catholique de Louvain Brussels, Belgium.

Fallot, J. M., \& Hertig, J. A. (2013). 2. Détermination des précipitations extrêmes en Suisse à l'aide d'analyses statistiques et augmentation des valeurs extrêmes durant le 20 ème siècle. Mém. Soc. Vaud Sc. Nat., 25, 13-24.

Forkuo, E. K. (2011). Flood hazard mapping using Aster image data with GIS. International journal of Geomatics and Geosciences, 1(4), 932-950.

Herman, G. V. (2010). Using Geographical Information (GIS) System for Management of Flood Risks in the Somes Plain. Cross-Border Partnership with Special Regard to the Hungarian-Romanian-Ukrainian Tripartite Border, 175-179.

Herman, G.V. (2009). Omul şi modificările antropice din Câmpia Someşului [The man and anthropogenic changes in Somes Plain], Editura Universității din Oradea.

Rifai, N., Khattabi, A., \& Rhazi, L. (2014). Modélisation des crues des rivières pour la gestion intégrée du risque d'inondation: cas du bassin versant de Tahaddart (nord-ouest du Maroc). Revue des sciences de l'eau/Journal of Water Science, 27(1), 57-69.

Sami, G., Abdelwahhab, F., \& Issam, K. M. (2020). Elaboration of an Erosion Map Using the Analytical Hierarchy Process (AHP) Case of the Region of Constantine (Algeria). Analele Universității din Oradea, Seria Geografie, 30(1), 1-9.

Sami, G., Hadda, D., \& Mahdi, K. (2016). Flood Hazard Map in the City of Batna (Algeria) by Hydraulic Modeling Approch. Analele Universității din Oradea, Seria Geografie, 26(1), 86-93.

Shamsi, S. U. (2002). GIS applications in floodplain management. In 2002 ESRI User Conference Proceedings, 22nd Annual ESRI International User Conference, July (pp. 8-12).

Simona, N., \& Cedric, L. (2007). Gestion durable des zones inondables dans le Delta du Danube (Roumanie). 1res Journées Scientifiques Inter-Réseaux de l'AUF, Gestion Intégrée des Eaux et des Sols. Ressources, Aménagements et Risques en Milieux Ruraux et Urbains, 6-9.

Wilcoxon, F. (1945). Individual comparisons by ranking methods. Biometrics, 1, 80-83.

Submitted:

December 05, 2019
Revised:

February 20, 2021
Accepted and published online

March 31, 2021 